\title{
Renal protection: a leading mechanism for cardiovascular benefit in patients treated with SGLT2 inhibitors
}

\author{
Davide Margonato ${ }^{1,2}$ (D) Giuseppe Galati ${ }^{3} \cdot$ Simone Mazzetti $^{1} \cdot$ Rosa Cannistraci ${ }^{4} \cdot$ Gianluca Perseghin $^{4}$. \\ Alberto Margonato $^{3} \cdot$ Andrea Mortara $^{1}$
}

Accepted: 31 August 2020 / Published online: 8 September 2020

(C) The Author(s) 2020

\begin{abstract}
Initially developed as glucose-lowering drugs, sodium-glucose co-transporter type 2 inhibitors (SGLT2i) have demonstrated to be effective agents for the risk reduction of cardiovascular (CV) events in patients with type 2 diabetes mellitus (T2DM). Subsequently, data has emerged showing a significant CV benefit in patients treated with SGLT2i regardless of diabetes status. Renal protection has been initially evaluated in CV randomized trials only as secondary endpoints; nonetheless, the positive results gained have rapidly led to the evaluation of nephroprotection as primary outcome in the CREDENCE trial. Different renal and vascular mechanisms can account for the $\mathrm{CV}$ and renal benefits enlightened in recent literature. As clinical guidelines rapidly evolve and the role of SGLT2i appears to become pivotal for CV, T2DM, and kidney disease management, in this review, we analyze the renal effects of SGLT2, the benefits derived from its inhibition, and how this may result in the multiple CV and renal benefits evidenced in recent clinical trials.
\end{abstract}

Keywords SGLT2 inhibitors - Chronic kidney disease - Type 2 diabetes mellitus · Renal protection · Cardiovascular outcomes · Heart failure

\section{Introduction}

Sodium-glucose co-transporter type 2 inhibitors (SGLT2i) were originally developed to reduce hyperglycemia in diabetic patients via an insulin-independent mechanism, through their glycosuric effect. However, over the past 5 years, evidence from randomized clinical trials (RCTs) showed an unexpected benefit and safety in most cardiovascular (CV) and renal outcomes, irrespective on their impact on glycemic control.

Davide Margonato

dvdmrgnt@gmail.com

1 Heart Failure Unit and Department of Cardiology, Policlinico di Monza, Via Amati 111, 20900 Monza, Italy

2 Department of Cardiology, Fondazione IRCCS Policlinico San Matteo, Pavia, Italy

3 Heart Failure Unit and Department of Cardiology, San Raffaele Hospital and Scientific Institute (IRCCS), Milan, Italy

4 Department of Medicine and Surgery, Università Degli Studi di Milano Bicocca, \& Policlinico di Monza, Monza, Italy
Chronic kidney disease (CKD) occurs in approximately $40 \%$ type 2 diabetes mellitus (T2DM) patients [1] and is associated with a very high risk of $\mathrm{CV}$ diseases [2]. Moreover, heart failure (HF) and CKD frequently coexist, sharing diabetes as one of the main risk factors, thus interacting in a vicious circle which contributes to a poor prognosis [3]. The growing evidence from many RCTs on SGLT2i as a CV protective class of drugs led to a class 1 level A recommendation for their use in patients with T2DM and established atherosclerotic CV disease (ACVD), or in patients with T2DM and multiple risk factors but without an ACVD [4]. More recently, SGLT2i showed to significantly reduce morbidity and mortality even in HF irrespective of diabetes status [4, 5].

Specific nephroprotection as a primary adjusted outcome has been evaluated only recently in the CREDENCE trial [6]; however, the mechanisms leading to renal benefit in patients treated with SGLT2i are still under debate.

This review focuses on the role of SGLT2i on kidney function, in order to clarify their potential direct and indirect benefits in preventing or delaying kidney damage, and on how this could translate into a reduction of $\mathrm{CV}$ and renal events as evidenced in recent trials. 


\section{The role of SGLTs in the kidney}

Sodium-glucose transporters (SGLTs) are cell-membrane symporters that transfer sodium, together with glucose, into the cell down and against the concentration gradient, respectively [7] (see Fig. 1). SGLT2 is a high-capacity low-affinity transporter located in the first segment of the proximal tubule and is responsible for the reabsorption of about $90 \%$ of filtered glucose. Residual glucose is reabsorbed by the high-affinity low-capacity transporter SGLT1 in the distal segment of the proximal tubule [9]. In an individual with preserved glomerular filtration rate (GFR) and normoglycemia, all the glucose filtered in the proximal tubules is reabsorbed; conversely, an increase in the concentration of plasma glucose leads to a constant increase in filtered glucose, until the threshold of reabsorption is reached (normally for values of glycemia around $180-215 \mathrm{mg} / \mathrm{dl}$ ) and glycosuria begins [10].

Diabetes mellitus is associated with an improved capacity of renal glucose reabsorption probably through an increased activity of SGLT2 in the proximal tubules, sustaining hyperglycemia in a sort of vicious cycle [11]. Whether this increased expression of SGLT2 is a result of persistent exposure to hyperglycemia is still unclear $[10,12]$.

It is important to underline that, although SGLT2 has the main quantitative role in tubular glucose reabsorption, the benefit of SGLT2i may be slightly blurred by the concomitant activity of SGLT1. However, a double block on SGLTs could lead to both an increase in glycosuria and an enhanced risk of hypoglycemic events.

\section{Direct renal benefits}

There are different direct effects of SGLT2i on kidney homeostasis that can explain the favorable renal outcomes reported in the literature. Firstly, SGLT2i, by reducing sodium reabsorption at the proximal tubules, causes an increase of sodium concentration at the macula densa, which in turn enhances sodium entrance in the cell and therefore its osmolarity [13]. The net effect is an increase in ATP's conversion to adenosine leading to vasoconstriction of the afferent arterioles - via the tubuloglomerular feedback - and to a reduction of GFR. This process is of paramount importance since it reduces glomerular hyperfiltration, intraglomerular pressure, and consequently barotrauma and proteinuria, which are typical events of the early stage of diabetic nephropathy and HF, thus slowing the progression of nephropathy $[14,15]$.

Osmotic diuresis induced by SGLT2i is particularly relevant in the situation of interstitial volume overload working in synergy with the other diuretics, in particular loop diuretics [16]. Indeed, it has been demonstrated that SGLT2i primarily reduces interstitial volume, with a minor effect on intravascular volume $[16,17]$, while loop diuretics mostly reduce intravascular volume. This synergistic effect of SGLT2i and loop diuretics on both intravascular and interstitial volumes is very useful in states of volume overload by also limiting adverse effects of other diuretics such as inappropriate reflex neurohormonal stimulation, a response to intravascular volume depletion, and uric acid levels increase [18, 19]. SGLT2i give a significant advantage particularly in HF because they reduce
Fig. 1 Effects of SGLT2 inhibition on the kidney and direct and indirect renal benefits obtained through SGLT2 inhibition (see in the text from reference 7 to reference 8 )

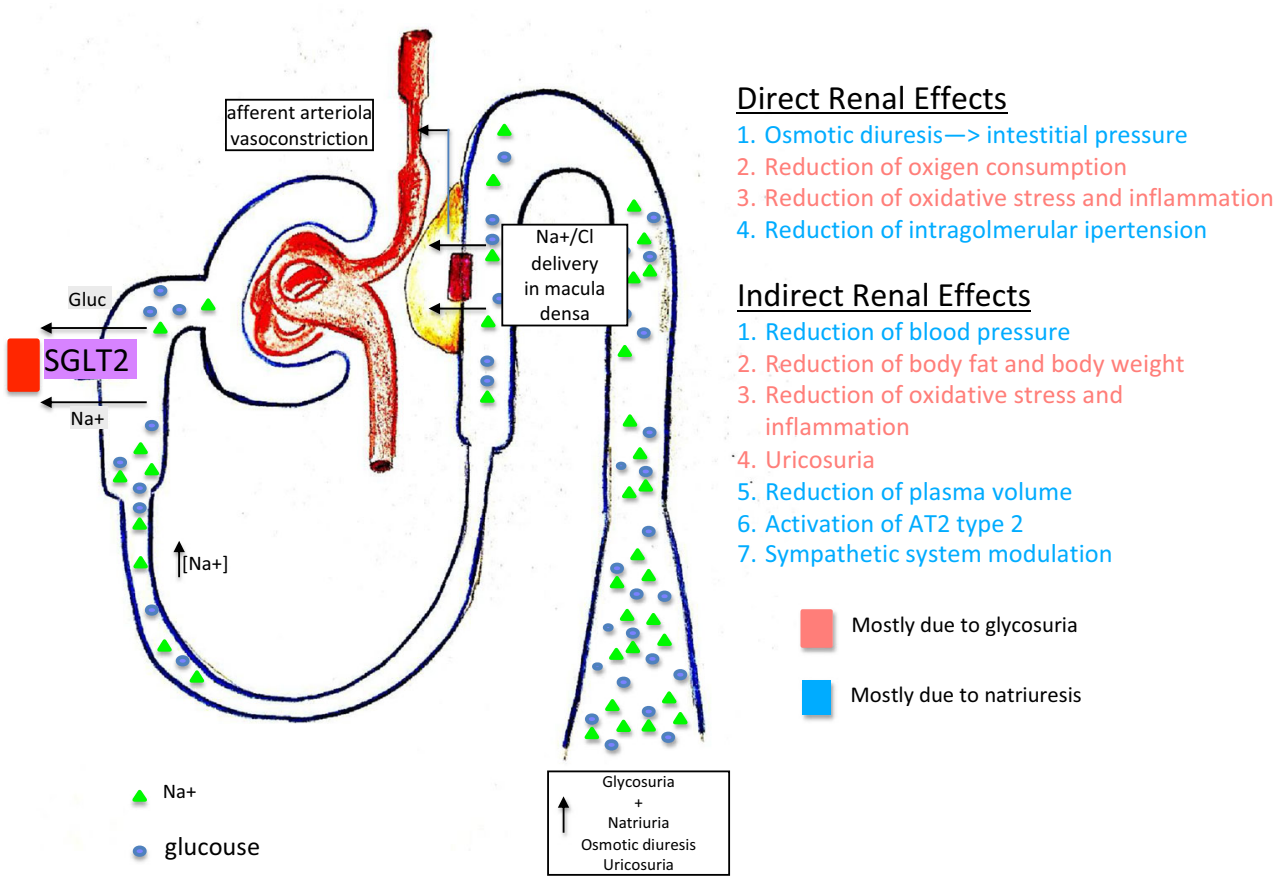


the need for the first introduction of a loop diuretic - as shown in EMPA-REG-Outcome-limiting the renin-angiotensinaldosterone system (RAAS) activation [20, 21]

SGLT2i also mitigates the direct kidney damage with a suppression of numerous pathways linked to tubular hypoxia and fibrosis, such as oxidative stress, and inflammasome activity [22-24] regardless of diabetes [25] together with a proven significant reduction of urinary excretion of inflammatory markers [26].

\section{Indirect renal benefits}

\section{Sympathetic nervous system}

Several systemic mechanisms can in part account for the nephroprotective properties of SGLT2i. Elevated sympathetic activity is widely known as a major risk factor for renal disease [27, 28] and a known feature of diabetic patients [29]. The cross-talk between the sympathetic nervous system and SGLT2 has been proved with compelling evidence in animal models: in fact, it has been demonstrated that chemical sympathetic denervation in neurogenic hypertensive mice resulted in reduced renal SGLT2 expression, and that dapagliflozintreated mice showed a significant decrease in the expression of markers of sympathetic activity and a reduction in blood pressure [30, 31]. The modulation of RAAS by SGLT2i has not been fully clarified. It has been suggested that this class of drugs activates the non-classic pathway of RAAS by stimulating the type 2 angiotensin II receptor with vasodilatation and anti-inflammatory properties, instead of the classic propathogenetic pathway via the type 1 angiotensin II receptors [32].

\section{Vascular protection}

The micro- and macrovascular protection derived from sustained control of glycemia, blood pressure, and lipid profile has been widely recognized also for SGLT2i [33]. Hypertension is independently associated with the risk of developing future complications in T2DM, and the positive impact of lowering blood pressure in T2DM seems even more important than treating hyperglycemia $[34,35]$. A reduction of systolic and diastolic blood pressure of 3-5 $\mathrm{mmHg}$ and 2$3 \mathrm{mmHg}$, respectively, has been reported with SGLT2i, both in monotherapy and in combination with other antidiabetic agents [36-38]. Natriuresis, a decrease in stress on vascular wall, and a reduction in body weight are the most important anti-hypertensive-related mechanisms [39-41]. Nonetheless, small reduction of blood pressure seems to be associated with minor renal benefit in the literature: in particular, as a reduction in albuminuria has been showed, favorable data on hard renal outcomes are controversial [42] but more recently emerging in the literature [43, 44].

\section{Weight loss}

A high body mass index (BMI) is one of the strongest risk factors for new-onset CKD [45], and the links between obesity and CKD are numerous and bidirectional [8]. Treatment with SGLT2 $\mathrm{i}$ is accompanied by consistent and sustained weight loss, mainly caused by a reduction in visceral adipose tissue [46-48]. Decreased insulin secretion, increased urinary glucose excretion, increased lipolysis, and fat oxidation are metabolic effects induced by SGLT-2 inhibition that seem to significantly contribute to weight loss [49].

\section{Cardiac benefit}

It is important to underline that the direct benefit of SGLT2i on the myocardium, especially in patients with HF or with an established cardiac disease, has beneficial effects also on kidney function and on renal outcomes. Direct effects on the myocardium are summarized in four main areas: reduction of left ventricular (LV) hypertrophy and mass and cardiomyocyte apoptosis; improvement of myocardial energetics and metabolomics; improvement of myocardial and ECM remodeling; reduction of myocardial inflammation and cytokines levels [21].

Finally, it is worth underlining that as the inhibition of SGLT2 is not insulin-dependent, the derived renal benefits abovementioned can be obtained during any phase of the natural history of diabetes, and the only limiting factor could be a severely reduced glomerular filtration rate, as in the end-stage renal disease (ESRD).

\section{Renal outcomes in RCTs on SGLT2 inhibitors: state of the art}

In 2008, the Food and Drug Administration requested, as mandatory, the assessment of CV safety outcomes in RCTs evaluating new glucose-lowering therapies. Since then, a large amount of evidence has emerged pointing toward a CV safety and efficacy of novel antidiabetic drugs. In particular, beneficial effects of SGLT2i on CV outcomes have been recently demonstrated by empagliflozin [50], canagliflozin [51], and dapagliflozin [52] in patients with established ACVD and in those with multiple risk factors but without an established ACVD.

Renal protection as a primary endpoint by SGLT2i treatment was evaluated only in the most recent CREDENCE trial [6]: nonetheless, data on the effects of SGLT2 on kidney function has been reported from secondary or exploratory endpoints (EPs) in CV trials (see Table 1). 
Table 1 Summary of renal data from renal and CV trials with SGLT2 inhibitors (specific references from the text are mentioned)

\begin{tabular}{|c|c|c|c|c|c|c|}
\hline & $\begin{array}{l}\text { Patients } \\
\text { (n.) }\end{array}$ & Drug & $\begin{array}{l}\text { Mean FU } \\
\text { (years) }\end{array}$ & Mean eGFR & Renal endpoint & $\mathrm{HR} / p$ value \\
\hline $\begin{array}{l}\text { EMPA-REG } \\
\text { OUTCOME } \\
\text { [50] }\end{array}$ & 7020 & Empagliflozin & 3,1 & $74.2 \mathrm{ml} / \mathrm{min} / 1.73 \mathrm{~m}^{2}$ & Rate of renal replacement therapy & $p=0.004$ \\
\hline $\begin{array}{l}\text { CANVAS Trial } \\
{[51]}\end{array}$ & 10,142 & Canaglflozin & 2,4 & $76.7 \mathrm{ml} / \mathrm{min} / 1.73 \mathrm{~m}^{2}$ & $\begin{array}{l}40 \% \text { reduction in eGFR, death from renal } \\
\text { cause or the need for renal } \\
\text { replacement therapy }\end{array}$ & $\begin{array}{l}\text { HR } 0.695 \% \text { IC } \\
0.47-0.77)\end{array}$ \\
\hline $\begin{array}{l}\text { DECLARE-TIMI } \\
58 \text { [52] }\end{array}$ & 17,160 & Dapagliflozin & 4.2 & $85.4 \mathrm{ml} / \mathrm{min} / 1.73 \mathrm{~m}^{2}$ & $\begin{array}{l}\text { Decrease in eGFR by at least } 40 \%, \mathrm{CV} \text { or } \\
\text { renal death and ESRD }\end{array}$ & HR $0.76 p<0.001$ \\
\hline DAPA-HF [5] & 4744 & Dapagliflozin & 1,6 & $66.0 \mathrm{ml} / \mathrm{min} / 1.73 \mathrm{~m}^{2}$ & $\begin{array}{l}\text { Sustained } \geq 50 \% \text { reduction in eGFR, } \\
\text { ESRD, or death from renal causes }\end{array}$ & $\begin{array}{l}\text { HR } 0.71 \text { CI } 0.44-1.16 \\
\quad p=0.17\end{array}$ \\
\hline $\begin{array}{l}\text { CREDENCE trial } \\
{[6]}\end{array}$ & 4401 & Canagliflozin & 2,6 & $56.3 \mathrm{ml} / \mathrm{min} / 1.73 \mathrm{~m} 2$ & $\begin{array}{l}\text { Composite of ESRD (dialysis, } \\
\text { transplantation, or a sustained eGFR } \\
\text { less than } 15 \mathrm{ml} / \mathrm{min} / 1.73 \mathrm{~m}^{2} \text { ), a } \\
\text { doubling of the serum creatinine level, } \\
\text { or death from renal or cardiovascular } \\
\text { cause }\end{array}$ & $\begin{array}{l}\text { HR } 0.70 ; 95 \% \text { CI } \\
\quad 0.59-0.82 \\
\quad p=0.00001\end{array}$ \\
\hline $\begin{array}{l}\text { Zelniker et al. } \\
\text { meta-analysis } \\
{[53]}\end{array}$ & 34,322 & & & & $\begin{array}{l}\text { Reduced the risk of renal disease } \\
\text { progression }\end{array}$ & HR 0.55 IC $0.48-0.64$ \\
\hline
\end{tabular}

In the 7020 patients with T2DM and established ACVD of the EMPA-REG OUTCOME [50], empagliflozin showed a significant $14 \%$ relative risk reduction (RRR) of the primary composite outcome (CV death, non-fatal myocardial infarction, or non-fatal stroke) driven by a $38 \% \mathrm{RR}$ reduction of $\mathrm{CV}$ mortality $(3.7 \%$ vs. $5.9 \%$; hazard ratio [HR] $0.62 ; 95 \%$ confidence interval $[\mathrm{CI}] 0.49-0.77, p<0.001)$ and a $35 \% \mathrm{RR}$ reduction of hospitalizations for $\mathrm{HF}(2.7 \%$ vs. $4.1 \%$, HR 0.65 ; $95 \%$ CI $0.5-$ $0.85, p=0.002$ ) which was consistent across predefined subgroups, including patients with and without a previous history of HF. The placebo and the empagliflozin pooled group had similar baseline eGFR $\left(73.8 \pm 21.1 \mathrm{ml} / \mathrm{min} / 1.73 \mathrm{~m}^{2}\right.$ vs $74.2 \pm$ $21.6 \mathrm{~m} / \mathrm{min} / \mathrm{m}^{2}$ ), but secondary renal EPs were significantly improved by empagliflozin. There was a $39 \%$ reduction of the established renal outcome such as progression of albuminuria, doubling of serum creatinine or ESRD, or renal death [54]. The rate of renal replacement therapy (RRT) was also lower in patients treated with empagliflozin compared with placebo ( $0.3 \%$ vs $0.6 \%$, HR $0.45,95 \%$ CI $0.21-0.97, p=0.04)$. In summary, in this trial, treated patients presented a significantly lower risk of CV events, but also of acute kidney injury compared with the placebo group [55]. Subsequently, it was shown that a major effect of empagliflozin consisted in an acute reduction of eGFR and albuminuria, followed by long-term stability and preservation of eGFR, compared with the doubling of eGFR deterioration in the placebo group over the same period of time (3.1 years of median follow-up) [56]. Renal benefits provided by empagliflozin was observed even in patients with compromised renal function, independently from baseline $\mathrm{HbAlc}$ and achieved regardless of concomitant medications interacting with renal function [57, 58].
The CANVAS trial [51] enrolled 10,142 T2DM patients, $66 \%$ with an established ACVD and 34\% with multiple risk factors without an established ACVD. Canagliflozin showed a $14 \% \mathrm{RR}$ reduction of the primary composite outcome (the same of the EMPA-REG) versus placebo, but with a significant effect only on HF hospitalizations (33\% RRR; $5.5 \%$ vs. $8.7 \%$; HR 0.67 ; $95 \%$ CI $0.52-0.87$ ), independently of the previous history of HF [51].

Even in the CANVAS trial, mean eGFR was similar in the placebo and canagliflozin groups $\left(76.2 \pm 20 \mathrm{ml} / \mathrm{min} / 1.73 \mathrm{~m}^{2}\right.$ vs $76.7 \pm 20.3 \mathrm{ml} / \mathrm{min} / 1.73 \mathrm{~m}^{2}$ ). The secondary endpoint of a sustained $40 \%$ reduction in eGFR, death from renal cause, or the need for renal replacement therapy (RRT) was significantly reduced by canagliflozin (HR $0.60 ; 95 \%$ CI $0.47-0.77$ ) [59]. Interestingly, the effect on $\mathrm{CV}$ and renal outcomes did not differ according to the presence of baseline CKD (defined as eGFR $<60 \mathrm{ml} / \mathrm{min} / 1.73 \mathrm{~m}^{2}$ ), albuminuria, eGFR, or BMI [58].

The third trial DECLARE-TIMI 58 [52] enrolled 17,160 T2DM patients and assessed the effects of dapagliflozin vs. placebo on $\mathrm{CV}$ outcomes. The majority of enrolled patients were without an established ACVD (59\%). Differently from the previous trials, DECLARE-TIMI 58 had a different design with two co-primary endpoints: MACE (CV death, MI, ischemic stroke) and CV death plus HF hospitalization. Indeed, noticing the unexpected beneficial effect on HF hospitalization both in EMPA-REG outcome and in CANVAS, it was decided to promote HF hospitalization as the primary endpoints. Despite a neutral effect on the MACE outcome, dapagliflozin was significantly superior to placebo in reducing $\mathrm{CV}$ death or HF hospitalization with a $17 \%$ reduction of the 
RR $(4.7 \%$ vs. $5.8 \%$; HR $0.83 ; 95 \%$, CI $0.73-0.95, p=0.005)$ [52]. When considered alone, the benefit was significant only for HF hospitalization (RRR 27\%; HR 0.73; 95\% CI 0.610.88 ) in patient with or without a previous history of HF [52]. In the DECLARE-TIMI 58, the mean eGFR was $85.4 \pm$ $15.8 \mathrm{ml} / \mathrm{min} / 1.73 \mathrm{~m}^{2}$ in the dapagliflozin group and $85.1 \pm$ $16.0 \mathrm{ml} / \mathrm{min} / 1.73 \mathrm{~m}^{2}$ in the placebo group. An analysis of this trial focused on secondary renal outcome has been reported [60], and it was showed that dapagliflozin reduced the risk of the composite cardiorenal outcome represented by sustained decrease in eGFR by at least $40 \%$ and CV or renal death and ESRD by $24 \%$ (HR $0.76 ; 95 \%$ CI $0.67-0.87, p<0.001$ ). The subgroup analyses revealed that the effect of dapagliflozin on CV outcomes was similar according to urinary albumin-tocreatinine ratio (UAC) $<$ or $>$ of $30 \mathrm{mg} / \mathrm{mmol}$ and to eGFR $<$ or $>$ of $60 \mathrm{ml} / \mathrm{min} / 1.73 \mathrm{~m}^{2}$ [52, 60].

Taking into consideration the results from EMPA-REG, CANVAS, and DECLARE-TIMI 58, Zelniker et al. have recently published a meta-analysis [53] on 34,322 patients showing that SGLT2i reduced the risk of renal disease progression by $45 \%$ (HR 0.55 ; 95\% CI $0.48-0.64, p<0.0001$ ), with a similar benefit in those with and without established ACVD. Nevertheless, an interaction between baseline renal function and the clinical effects of SGLT2i was noted. The authors divided patients in three groups according to the values of eGFR of less than $60 \mathrm{ml} / \mathrm{min} / 1.73 \mathrm{~m}^{2}$, between 60 and $90 \mathrm{ml} / \mathrm{min} /$ $1.73 \mathrm{~m}^{2}$, and equal or above $90 \mathrm{ml} / \mathrm{min} / 1.73 \mathrm{~m}^{2}$. Reduction of the standardized composite endpoint of renal outcomes including worsening eGFR, ESRD, or renal death was observed across all baseline eGFR values but was more relevant in the group with eGFR $\geq 90 \mathrm{ml} / \mathrm{min} / 1.73 \mathrm{~m}^{2}$ [59]. By contrast, the more pronounced risk reduction for HF hospitalization was reported in patients with eGFR values of less than $60 \mathrm{ml} / \mathrm{min} /$ $1.73 \mathrm{~m}^{2}$ [53]. The potential reasons for these results are a topic of active investigation: possibly, the nephroprotective effects induced by SGLT2i and described in our review, in particular the natriuretic effect, could explain the benefits enlightened in patients with worse baseline eGFR, a category at higher risk for HF hospitalization, whereas the greatest reduction of renal composite outcome in those with baseline preserved renal function could be explained by a more pronounced long-term protection of a preserved renovascular structure compared with the protection of SGLT2i obtained in a stage of mild or moderate renal dysfunction, when the damage is only partially reversible. Another recent meta-analysis [61] focused on the effects of both SGLT2i and glucagon-like peptide 1 receptor agonists (GLP1$\mathrm{RA})$ on $\mathrm{CV}$ and renal outcomes. The authors demonstrated that both GLP1-RA (HR 0.82; 95\% CI 0.75-0.89; $p<0.001$ ) and SGLT2i (HR 0.62 ; 95\% CI $0.58-0.67, p<0.001$ ) reduced the risk of progression of kidney disease including macroalbuminuria, but only SGLT2i reduced the risk of worsening eGFR, end-stage kidney disease, or renal death (HR 0.55; 95\% CI 0.48-0.64, $p<0.001)$ [61].
DAPA-HF [5] was the first RCT on SGLT2i dedicated to HF patients irrespective of diabetic status. It enrolled $4744 \mathrm{HFrEF}$ patients to receive dapagliflozin or placebo on top of standard of care therapy for HFrEF. The primary outcome was a composite of CV death plus HF hospitalization or an urgent visit for worsening HF. After a median follow-up of 18.2 months, dapagliflozin significantly reduced the primary EP of $26 \%$ (HR 0.74; 95\% CI 0.65-0.85, $p=0.00001$ ) [5]. The different components of the primary EP were all significantly reduced: CV mortality by $18 \%$ (HR 0.82 ; 95\% CI $0.69-0.98, p=0.029$ ) and first hospitalization for HF or urgent visit for HF by $30 \%$ (HR 0.70; 95\% CI 0.59-0.83, $p=0.00003$ ) [5]. Moreover, also all the secondary endpoints were significantly reduced: $\mathrm{CV}$ mortality and first hospitalization for HF (HR $0.75 ; 95 \%$ CI 0.65 $0.85, p=0.00002), \mathrm{CV}$ mortality and all the hospitalizations for HF (HR $0.75 ; 95 \%$ CI $0.65-0.88, p=0.0002$ ), and all-cause mortality (HR $0.83 ; 95 \%$ CI $0.71-0.97, p=0.022$ ) [5].

The most remarkable result was the reduction of the primary endpoints also in non-diabetic patients, as documented by the prespecified subgroup analyses which did not show any difference regarding the reduction or primary endpoints between diabetic patients (HR $0.75 ; 95 \%$ CI $0.63-0.90$ ) and non-diabetic patients (HR 0.73; 95\% CI 0.60-0.88) [5]. In particular, non-diabetic patients had a RR reduction of $27 \%$ of the primary endpoint.

Regarding the renal outcome, DAPA-HF enrolled a population with a mean eGFR of 66.0 and $65.5 \mathrm{ml} / \mathrm{min} / 1.73 \mathrm{~m}^{2}$ in treated and placebo groups, respectively. However, differently from the previous RCTs, $40.6 \%$ and $40.7 \%$ in dapagliflozin and placebo groups had an eGFR $\geq 30$ and $<60 \mathrm{ml} / \mathrm{min} /$ $1.73 \mathrm{~m}^{2}$, whereas the previous $3 \mathrm{RCTs}$ excluded patients with an eGFR $<60 \mathrm{ml} / \mathrm{min} / 1.73 \mathrm{~m}^{2}$. In this population with a more severe CKD, dapagliflozin vs placebo showed no differences regarding the incidence of the secondary endpoint "worsening renal function," a composite of sustained $\geq 50 \%$ reduction in eGFR, ESRD, or death from renal causes (HR $0.71 ; 95 \%$ CI $0.44-1.16, p=0.17$ ) but showed a trend of benefit for dapagliflozin group (worsening renal function occurred in $1.2 \%$ of the dapagliflozin group vs $1.6 \%$ of controls) [58]. Noteworthy, the prespecified subgroup analysis did not detected any difference regarding the reduction of primary EP in patients with an $\mathrm{eGFR} \geq 60 \mathrm{ml} / \mathrm{min} / 1.73 \mathrm{~m}^{2}$ with respect to the patient with an eGFR $<60 \mathrm{ml} \mathrm{ml} / \mathrm{min} / 1.73 \mathrm{~m}^{2}$ [5].

In summary, the previously mentioned 3 RCTs were focused on CVD prevention in T2DM, and they were not originally designed to explore primarily the role of SGLT2i on renal outcome. In fact, they included a limited number of patients with mild $\mathrm{CKD}$, with the consequence of observing a small number of renal events such as dialysis, renal transplantation, or renal death: however, the unexpected magnitude of beneficial effect on secondary kidney outcome gained attention, increasing the expectation for the results of the trials with renal endpoints as primary target. 


\section{The CREDENCE trial}

The first of the SGLT2i RCT with a primary cardiorenal composite endpoint was the CREDENCE trial [6]. This trial randomized 4401 patients with TD2M and albuminuric CKD, defined as values of eGFR $\geq 30$ and $<90 \mathrm{ml} / \mathrm{min} / 1.73 \mathrm{~m}^{2}$ and UAC between 300 and $5000 \mathrm{mg} / \mathrm{g}$, to receive either $100 \mathrm{mg}$ daily of canagliflozin or placebo; all patients were treated with RAAS blockade and $50 \%$ had a history of CV disease. The primary outcome was a composite endpoint of ESRD (defined as dialysis, transplantation, or a sustained eGFR less than $15 \mathrm{ml} / \mathrm{min} / 1.73 \mathrm{~m}^{2}$ ), a doubling of the serum creatinine level, or death from renal or cardiovascular cause.

The trial was stopped early, with a median follow-up of 2.6 years, after a planned ad interim analysis. At that time, the event rate of the primary endpoint was significantly reduced in the canagliflozin group compared with placebo, with a RR reduction of $30 \%$ (HR $0.70 ; 95 \%$ CI $0.59-0.82, p=$ 0.00001 ) [6]. In addition, patients randomized to canagliflozin presented a significant RRR of 34\% (HR 0.66; 95\% CI 0.53$0.8, p<0.001$ ) for the renal composite outcome of ESRD, doubling of the serum creatinine level, or renal death [6]; the nephroprotective role of canagliflozin was consistent also for the single components of composite endpoint ESRD (HR $0.68 ; 95 \%$ CI $0.54-0.86, p=0.002$ ) and for the exploratory outcome of dialysis, kidney transplantation, or renal death (HR $0.72 ; 95 \%$ CI 0.54 to 0.97 ) [6].

Once more, after the first weeks of treatment, there was an initial greater reduction of eGFR in the canagliflozin than in the placebo group $\left(-3.72 \pm 0.25 \mathrm{vs.}-0.55 \pm 0.25 \mathrm{ml} / \mathrm{min} / 1.73 \mathrm{~m}^{2}\right.$; $95 \%$ CI, -3.87 to -2.47 ) [6]; afterwards, the reduction of eGFR was slower in the canagliflozin group than in the placebo group $\left(-1.85 \pm 0.13\right.$ vs. $-4.59 \pm 0.14 \mathrm{ml} / \mathrm{min} / 1.73 \mathrm{~m}^{2}$ per year; $95 \%$ CI, 2.37 to 3.11) [6]. Several secondary CV outcomes were tested in a hierarchical fashion: canagliflozin reduced the relative risk of the composites of $\mathrm{CV}$ death or hospitalization for $\mathrm{HF}$ (HR 0.69 ; 95\% CI 0.57.0.83, $p<0.001$ ), CV death, myocardial infarction, or stroke (HR 0.80; 95\% CI 0.67-0.95, $p=0.01$ ), and hospitalization for $\mathrm{HF}(\mathrm{HR} 0.61 ; 95 \%$ CI $0.47-0.80, p<0.001$ ) [6]. These findings strongly support the concept that canagliflozin may have clear and relevant effects for both renal and $\mathrm{CV}$ protection in patients with $\mathrm{T} 2 \mathrm{DM}$ and $\mathrm{CKD}$; furthermore, the authors suggested that the benefits observed in the CREDENCE trial were also consistent regardless of baseline diuretic use, different levels of hypertension or glucose control, and weight loss [62].

\section{Conclusions}

Despite that SGLT2i were originally thought and developed as glucose-lowering drugs, unexpectedly, they documented a significative reduction of death and $\mathrm{CV}$ events even in the absence of diabetes and demonstrated a cardiorenal protective effects. Whereas different trials mainly focused on prevention of $\mathrm{CV}$ outcomes in TD2M patients, there was a clear benefit on HF that was initially explored only as secondary endpoint. Later on, the DAPA-HF trial proved a clear benefit on $\mathrm{CV}$ mortality and worsening HF both in diabetic and in non-diabetic patients but also in patients with a moderate to severe CKD. Likewise, there was an unforeseen benefit in renal outcomes-initially evaluated only in patients with a mild CKD - that taken together with HF hospitalization dragged most of the benefit in the 3 RCTs dedicated to CVD prevention [50-52].

The CREDENCE trial demonstrated the role of canagliflozin in reducing the risk of kidney failure, analyzed as primary outcome, and CV events in patients with T2DM and CKD, and thanks to the CREDENCE trial, the European Medicines Agency's (EMA) Committee for Medicinal Products for Human Use (CHMP) has adopted a positive opinion to extend the indication of canagliflozin (at the lower dose of $100 \mathrm{mg}$ day) to include important renal outcomes.

In line with the CREDENCE trial, in patients with T2DM post hoc analysis [63] of two registration trials with ertugliflozin, a new drug in the class with high selectivity for SGLT2, confirmed that over 104 weeks of treatment, eGFR values were higher and UAC reduced compared with nonSGLT2i treatment, even though changes in HbA1c did not differ between the groups; with respect to this drug, data from the CV safety VERTIS trial, recently presented at the American Diabetes Association, including secondary composite renal endpoints are eagerly awaited.

The effects in the kidney derived from SGLT2 inhibition are likely to be multifactorial, with different direct and indirect mechanisms. Additional studies will clarify the potential clinical role of SGLT2i on kidney function in patients without T2DM: at this stage, we have data generated following a very short period of time ( 6 weeks) of treatment with dapagliflozin, the DIAMOND trial [64], in which patients with nondiabetes-related CKD did not show a beneficial effect on proteinuria when compared with the placebo group. The effects of a longer period of treatments are warranted.

In the meantime, taking into consideration the bidirectional nature of the heart-kidney interplay, the susceptibility of T2DM patients to develop HF and CKD, and the results of the CVD safety trails, of the CREDENCE trial and of DAPA$\mathrm{HF}$, we believe that this class of drugs has already become a milestone therapy for cardiorenal protection in patients with T2DM and in patients with HF.

Acknowledgements Open access funding provided by Università degli Studi di Pavia within the CRUI-CARE Agreement.

Authors' contributions All the authors contributed to the study conception and design. The first draft of the manuscript was written by Dr. D. 
Margonato, and all the authors commented on previous versions of the manuscript. All the authors read and approved the final manuscript.

\section{Compliance with ethical standards}

Conflict of interest The authors declare that they have no conflicts of interest.

Open Access This article is licensed under a Creative Commons Attribution 4.0 International License, which permits use, sharing, adaptation, distribution and reproduction in any medium or format, as long as you give appropriate credit to the original author(s) and the source, provide a link to the Creative Commons licence, and indicate if changes were made. The images or other third party material in this article are included in the article's Creative Commons licence, unless indicated otherwise in a credit line to the material. If material is not included in the article's Creative Commons licence and your intended use is not permitted by statutory regulation or exceeds the permitted use, you will need to obtain permission directly from the copyright holder. To view a copy of this licence, visit http://creativecommons.org/licenses/by/4.0/.

\section{References}

1. Licic RZ, Rooney MT, Tuttle KR (2017) Diabetic kidney disease: challenges, progress and possibilities. Clin J Am Soc Nephrol 12: 2032-2045

2. Arwar N, Gao P, Seshasai SR, Gobin R, Kaptoge S, Di Angelantonio E et al (2010) Diabetes mellitus, fasting blood glucose concentration, and risk of vascular disease: a collaborative meta-analysis of 102 prospective studies. Lancet 375:2215-2222

3. Amman K, Valente MAE, Voors AA, O'Connor CM, van Veldhuisen DJ, Hillege HL (2014) Renal impairment, worsening renal function, and outcome in patients with heart failure: an updated meta-analysis. Eur Heart J 35:455-469

4. Cosentino F, Grant PJ, Aboyans V, Bailey CJ, Ceriello A, Delgado V, Federici M, Filippatos G, Grobbee DE, Hansen TB, Huikuri HV, Johansson I, Jüni P, Lettino M, Marx N, Mellbin LG, Östgren CJ, Rocca B, Roffi M, Sattar N, Seferović PM, Sousa-Uva M, Valensi P, Wheeler DC, ESC Scientific Document Group, Piepoli MF, Birkeland KI, Adamopoulos S, Ajjan R, Avogaro A, Baigent C, Brodmann M, Bueno H, Ceconi C, Chioncel O, Coats A, Collet JP, Collins P, Cosyns B, di Mario C, Fisher M, Fitzsimons D, Halvorsen S, Hansen D, Hoes A, Holt RIG, Home P, Katus HA, Khunti K, Komajda M, Lambrinou E, Landmesser U, Lewis BS, Linde C, Lorusso R, Mach F, Mueller C, Neumann FJ, Persson F, Petersen SE, Petronio AS, Richter DJ, Rosano GMC, Rossing P, Rydén L, Shlyakhto E, Simpson IA, Touyz RM, Wijns W, Wilhelm M, Williams B, Aboyans V, Bailey CJ, Ceriello A, Delgado V, Federici M, Filippatos G, Grobbee DE, Hansen TB, Huikuri HV, Johansson I, Jüni P, Lettino M, Marx N, Mellbin LG, Östgren CJ, Rocca B, Roffi M, Sattar N, Seferović PM, Sousa-Uva M, Valensi P, Wheeler DC, Windecker S, Aboyans V, Baigent C, Collet JP, Dean V, Delgado V, Fitzsimons D, Gale CP, Grobbee DE, Halvorsen S, Hindricks G, Iung B, Jüni P, Katus HA, Landmesser U, Leclercq C, Lettino M, Lewis BS, Merkely B, Mueller C, Petersen SE, Petronio AS, Richter DJ, Roffi M, Shlyakhto E, Simpson IA, Sousa-Uva M, Touyz RM, Zelveian PH, Scherr D, Jahangirov T, Lazareva I, Shivalkar B, Naser N, Gruev I, Milicic D, Petrou PM, Linhart A, Hildebrandt P, Hasan-Ali H, Marandi T, Lehto S, Mansourati J, Kurashvili R, Siasos G, Lengyel C, Thrainsdottir IS, Aronson D, di Lenarda A, Raissova A, Ibrahimi P, Abilova S, Trusinskis K, Saade G, Benlamin H, Petrulioniene Z,
Banu C, Magri CJ, David L, Boskovic A, Alami M, Liem AH, Bosevski M, Svingen GFT, Janion M, Gavina C, Vinereanu D, Nedogoda S, Mancini T, Ilic MD, Fabryova L, Fras Z, JiménezNavarro MF, Norhammar A, Lehmann R, Mourali MS, Ural D, Nesukay E, Chowdhury TA (2020) 2019 ESC guidelines on diabetes, pre-diabetes, and cardiovascular diseases developed in collaboration with the EASD. Eur Heart J 41:255-323

5. McMurray JJV, Solomon SD, Inzucchi SE, Køber L, Kosiborod MN, Martinez FA, Ponikowski P, Sabatine MS, Anand IS, Bělohlávek J, Böhm M, Chiang CE, Chopra VK, de Boer RA, Desai AS, Diez M, Drozdz J, Dukát A, Ge J, Howlett JG, Katova T, Kitakaze M, Ljungman CEA, Merkely B, Nicolau JC, O'Meara E, Petrie MC, Vinh PN, Schou M, Tereshchenko S, Verma S, Held C, DeMets D, Docherty KF, Jhund PS, Bengtsson O, Sjöstrand M, Langkilde AM, DAPA-HF Trial Committees and Investigators (2019) DAPA-HF trial committees and investigators. Dapagliflozin in patients with heart failure and reduced ejection fraction. N Engl J Med 381(21):1995-2008. https://doi.org/10. 1056/NEJMoa1911303

6. Perkovic V, Jardine MJ, Neal B, Bompoint S, Heerspink HJL, Charytan DM, Edwards R, Agarwal R, Bakris G, Bull S, Cannon CP, Capuano G, Chu PL, de Zeeuw D, Greene T, Levin A, Pollock C, Wheeler DC, Yavin Y, Zhang H, Zinman B, Meininger G, Brenner BM, Mahaffey KW, CREDENCE Trial Investigators (2019) Canagliflozin and renal outcomes in type 2 diabetes and nephropathy. N Engl J Med 380(24):2295-2306

7. Hediger MA, Rhoads DB (1994) Molecular physiology of sodiumglucose cotransporters. Physiol Rev 74:993-1026

8. Lakkis JI, Weir MR (2018) Obesity and Kidney Disease. Prog Cardiovasc Dis 61(2):157-167

9. Wright EM, Loo DDF, Hirayama BA (2011) Biology of human sodium glucose transporters. Physiol Rev 91:733-794

10. Tahrani AA, Barnett AH, Bailey CJ (2013) SGLT inhibitors in management of diabetes. Lancet Diabetes Endocrinol 1:140-151

11. Lee YJ, Lee YJ, Han HJ (2007) Regulatory mechanisms of Na+/ glucose cotransporters in renal proximal tubule cells. Kidney Int 72: S27-S35

12. Allon V (2011) The proximal tubule in the pathophysiology of the diabetic kidney. Am J Physiol Regul Integr Comp Physiol 300: R1009-R1022

13. Heerspink HJ, Perkins BA, Fitchett DH, Husain M, Cherney DZ (2016) Sodium glucose cotransporter 2 inhibitors in the treatment of diabetes mellitus: cardiovascular and kidney effects, potential mechanisms, and clinical applications. Circulation. 134(10):752772

14. Cherney DZ, Perkins BA, Soleymanlou N, Maione M, Lai V, Lee A (2014) Renal hemodynamic effect of sodium-glucose cotransporter 2 inhibition in patients with type 1 diabetes mellitus. Circulation. 129(5):587-597

15. Rajasekeran H, Lytvyn Y, Bozovic A, Lovshin J, Diamandis E, Cattran D et al (2017) Urinary adenosine excretion in type 1 diabetes. Am J Physiol Renal Physiol 313:F184-F191

16. Griffin M, Rao VS, Ivey-Miranda J, Fleming J, Mahoney D, Maulion C, Suda N, Siwakoti K, Ahmad T, Jacoby D, Riello R, Bellumkonda L, Cox Z, Collins S, Jeon S, Turner JM, Wilson FP, Butler J, Inzucchi SE, Testani JM (2020) Empagliflozin in heart failure: diuretic and cardio-renal effects. Circulation. https://doi. org/10.1161/CIRCULATIONAHA.120.045691

17. Hallow KM, Helmlinger G, Greasley PJ, McMurray JJV, Boulton DW (2018) Why do SGLT2 inhibitors reduce heart failure hospitalization? A differential volume regulation hypothesis. Diabetes Obes Metab 20:479-487

18. Verma S, John JV (2018) McMurray SGLT2 inhibitors and mechanisms of cardiovascular benefit: a state-of-the-art review. Diabetologia 61:2108-2117 
19. Wilcox CS, Shen W, Boulton DW, Leslie BR, Griffen SC (2018) Interaction between the sodium-glucose-linked transporter 2 inhibitor dapagliflozin and the loop diuretic bumetanide in normal human subjects. J Am Heart Assoc 7:e007046

20. Januzzi J, Ferreira JP, Böhm M, Kaul S, Wanner C, Brueckmann M, Petrie MC, Ofstad AP, Zeller C, George J, Fitchett D, Zannad F (2019) Empagliflozin reduces the risk of a broad spectrum of heart failure outcomes regardless of heart failure status at baseline. Eur J Heart Fail 21(3):386-388. https://doi.org/10.1002/ejhf.1419

21. Sabouret P, Galati G, Angoulvant D, Germanova O, Castelletti S, Pathak A et al (2020) The interplay between cardiology and diabetology: a renewed collaboration to optimize cardiovascular prevention and heart failure management. Eur Heart J Cardiovasc Pharmacother 13:pvaa051. https://doi.org/10.1093/ehjcvp/pvaa051

22. Hodrea J, Balogh DB, Hosszu A, Lenart L, Besztercei B, Koszegi S et al (2020) Reduced O-GlcNAcylation and tubular hypoxia contribute to the antifibrotic effect of SGLT2 inhibitor dapagliflozin in the diabetic kidney. Am J Physiol Renal Physiol 318(4)

23. Woods TC, Satou R, Miyata K, Katsurada A, Dugas CM, Klingenberg NC, Fonseca VA, Navar LG (2019) Canagliflozin prevents intrarenal angiotensinogen augmentation and mitigates kidney injury and hyper- tension in mouse model of type 2 diabetes mellitus. Am J Nephrol 49:331-342

24. Yaribeygi H, Katsiki N, Butler AE, Sahebkar A (2019) Effects of antidiabetic drugs on NLRP3 inflammasome activity, with a focus on diabetic kidneys. Drug Discov Today 24:256-262

25. Castoldi G, Carletti R, Ippolito S, Colzani M, Barzaghi F, Stella A, Zerbini G, Perseghin G, di Gioia CRT (2020) Renal antifibrotic effect of sodium glucose cotransporter-2 inhibition in angiotensin II dependent hypertension. Am J Nephrol 51:119-129

26. Dekkers CCJ, Petrykiv S, Laverman GD, Cherney DZ, Gansevoort RT, Heerspink HJL (2018) Effects of the SGLT-2 inhibitor dapagliflozin on glomerular and tubular injury markers. Diabetes Obes Metab 20(8):1988-1993

27. Schlaich M, Straznicky N, Lambert E, Lambert G (2015) Metabolic syndrome: a sympathetic disease? Lancet Diabetes Endocrinol 3: $148-157$

28. Thorp A, Schlaich M (2015) Relevance of sympathetic nervous system activation in obesity and meta- bolic syndrome. J Diabetes Res 2015:341583

29. Grassi G, Biffi A, Dell'Oro R, Quarti Trevano F, Seravalle G et al (2020) Sympathetic neural abnormalities in type 1 and type 2 diabetes: a systematic review and meta-analysis. J Hypertens. https:// doi.org/10.1097/HJH.0000000000002431

30. Herat LY, Magno AL, Rudnicka C, Hricova J, Carnagarin R, Ward NC et al (2020) SGLT2 inhibitor-induced Sympathoinhibition a novel mechanism for cardiorenal protection. JACC Basic Transl Sci 5(2):169-179

31. Matthews V, Elliot R, Rudnicka C, Hricova J, Herat L, Schlaich M (2017) Role of the sympathetic ner- vous system in regulation of the sodium glucose co-transporter 2. J Hypertens 35:2059-2068

32. Muskiet MH, van Raalte DH, van Bommel EJ, Smits MM, Tonneijck L (2015) Understanding EMPA-REG OUTCOME. Lancet Diabetes Endocrinol 3(12):928-929

33. Ferrannini E, Solini A (2012) SGLT2 inhibition in diabetes mellitus: rationale and clinical prospects. Nat Rev Endocrinol 8: 495-502

34. Stratton IM, Cull CA, Adler AI, Matthews DR, Neil HA, Holman RR (2006) Additive effects of glycaemia and blood pressure exposure on risk of complications in type 2 diabetes: a prospective observational study (UKPDS 75). Diabetologia 49:1761-1769

35. UK Prospective Diabetes Study (UKPDS) Group (1998) Intensive blood-glucose control with sulphonylureas or insulin compared with conventional treat- ment and risk of complications in patients with type 2 diabetes (UKPDS 33). Lancet 352:837-853
36. Tikkanen I, Chilton R, Johansen OE (2016) Potential role of sodium glucose cotransporter 2 inhibitors in the treatment of hypertension. Curr Opin Nephrol Hypertens 25(2):81-86

37. Nauck MA, Del Prato S, Meier JJ, Durán-García S, Rohwedder K, Elze $\mathrm{M}$ et al (2011) Dapagliflozin versus glipizide as add-on therapy in patients with type 2 diabetes who have inadequate glycemic control with metformin: a randomized, 52-week, double-blind, active-controlled noninferiority trial. Diabetes Care 34:2015-2022

38. Wilding JPH, Norwood P, T'joen C, Bastien A, List JF, Fiedorek FT (2009) A study of dapagliflozin in patients with type 2 diabetes receiving high doses of insulin plus insulin sensitizers: applicability of a novel insulin-independent treatment. Diabetes Care 32:16561662

39. Kimura G (2016) Importance of inhibiting sodium-glucose cotransporter and its compelling indication in type 2 diabetes: pathophysiological hypothesis. J Am Soc Hypertens 10(3):271-278

40. Cefalu WT, Stenlöf K, Leiter LA, Wilding JP, Blonde L, Polidori D et al (2015) Effects of canagliflozin on body weight and relationship to $\mathrm{HbA} 1 \mathrm{c}$ and blood pressure changes in patients with type 2 diabetes. Diabetologia 58(6):1183-1187

41. Cherney DZ, Perkins BA, Soleymanlou N, Har R, Fagan N, Johansen OE et al (2014) The effect of empa-gliflozin on arterial stiffness and heart rate variability in subjects with uncomplicated type 1 diabetes mellitus. Cardiovasc Diabetol 13:28

42. Scheen AJ, Delanaye P (2017) Effects of reducing blood pressure on renal outcomes in patients with type 2 diabetes: focus on SGLT2 inhibitors and EMPA-REG OUTCOME. Diabetes Metab 43(2): 99-109

43. Coresh J, Heerspink HJL, Sang Y, Matsushita K, Arnlov J, Astor BC, Black C, Brunskill NJ, Carrero JJ, Feldman HI, Fox CS, Inker LA, Ishani A, Ito S, Jassal S, Konta T, Polkinghorne K, Romundstad S, Solbu MD, Stempniewicz N, Stengel B, Tonelli M, Umesawa M, Waikar SS, Wen CP, Wetzels JFM, Woodward M, Grams ME, Kovesdy CP, Levey AS, Gansevoort RT, Appel LJ, Greene T, Chen TK, Chalmers J, Arima H, Perkovic V, Levin A, Djurdjev O, Tang M, Nally J, Navaneethan SD, Schold JD, Weldegiorgis M, Herrington WG, Smith M, Hsu CY, Hwang SJ, Chang AR, Kirchner HL, Green JA, Ho K, Marks A, Prescott G, Clark LE, Fluck N, Shalev V, Chodick G, Blankestijn PJ, van Zuilen A, van den Brand JA, Sarnak MJ, Bottinger E, Nadkarni GN, Ellis SG, Nadukuru R, Metzger M, Flamant M, Houillier P, Haymann JP, Froissart M, Kenealy T, Elley RC, Collins JF, Drury PL, Cuddeback JK, Ciemins EL, Stempniewicz R, Nelson RG, Knowler WC, Bakker SJ, Major RW, Medcalf JF, Shepherd D, Barrett-Connor E, Bergstrom J, Ix JH, Molnar MZ, Sumida K, de Zeeuw D, Brenner B, Qureshi AR, Elinder CG, Runesson B, Evans M, Segelmark M, Stendahl M, Schön S, Naimark DM, Tangri N, Sud M, Hirayama A, Ichikawa K, Bilo HJG, Landman GWD, van Hateren KJJ, Kleefstra N, Hallan SI, Ballew SH, Chen J, Kwak L, Surapaneni A, Parving HH, Rodby RA, Rohde RD, Lewis JB, Lewis E, Perrone RD, Abebe KZ, Hou FF, Xie D, Hunsicker LG, Imai E, Kobayashi F, Makino H, Ito S, Remuzzi G, Ruggenenti P, Eckardt KU, Gudmundsdottir H, Maciulaitis R, Manley T, Smith K, Stockbridge N, Thompson A, Vetter T, Willis K, Zhang L (2019) Chronic kidney disease prognosis consortium and chronic kidney disease epidemiology collaboration. Change in albuminuria and subsequent risk of end-stage kidney disease: an individual participant-level consortium meta-analysis of observational studies. Lancet Diabetes Endocrinol 7:115-127

44. Heerspink HJL, Greene T, Tighiouart H, Gansevoort RT, Coresh J, Simon AL, Chan TM, Hou FF, Lewis JB, Locatelli F, Praga M, Schena FP, Levey AS, Inker LA, Sevillano A, Kamper AL, van Zuilen AD, Brenner BM, Maes B, Ihle BU, Barret B, Leung CB, Szeto CC, Fitzner C, Wanner C, Pozzi C, Montagnino CP, Xie D, de Zeeuw D, Lewis E, Verde E, Gutierrez E, Imai E, Hou FF, Caravaca F, Fervenza FC, Locatelli F, Schena FP, Kobayashi F, 
Moroni G, Becker GJ, Beck GJ, Appel GB, Frisch G, van Essen G, Maschio G, Remuzzi G, Montogrino G, Parving HH, Heerspink HJL, Makino H, Jehan I, Wetzels JFM, Donadio J, Dwyer J, van den Brand J, Kusek J, Lachin JM, Luño J, Lewis JB, Floege J, Abebe KZ, Chow KM, Hunsicker LG, del Vecchio L, Carlo M, Praga M, Goicoechea M, von Eynatten M, Poulter N, Chaturvedi N, Passerini P, de Jong PE, Blankestijn PJ, Li P, Ruggenenti P, Zucchelli P, Kincaid-Smith PS, Hilgers RD, Estacio RO, Rohde RD, Katafuchi R, Toto RD, Schrier RW, Rodby RA, Perrone RD, Ito S, Klahr S, Andrulli S, Strandgaard S, Chan TM, Hannedouche TP, Rauen T, Greene T, Verdalles U, Perkovic V, Keane W (2019) Chronic kidney disease epidemiology collaboration. Change in albuminuria as a surrogate endpoint for progression of kidney disease: a meta-analysis of treatment effects in randomised clinical trials. Lancet Diabetes Endocrinol 7:128-139

45. Kovesdy CP, Furth SL, Zoccali C (2017) Obesity and kidney disease: hidden consequences of the epidemic. Afr J Prim Health Care Fam Med 26:9(1)

46. Henry RR, Murray AV, Marmolejo MH, Hennicken D, Ptaszynska A, List JF (2012) Dapagliflozin, metformin XR, or both: initial pharmacotherapy for type 2 diabetes, a randomised controlled trial. Int J Clin Prac 66:446-456

47. Bolinder J, Ljunggren Ö, Kullberg J, Johansson L, Wilding J, Langkilde AM, Sugg J, Parikh S (2012) Effects of dapagliflozin on body weight, total fat mass, and regional adipose tissue distribution in patients with type 2 diabetes mellitus with inadequate glycemic control on metformin. J Clin Endocrinol Metab 97: 1020-1031

48. Clar C, Gill JA, Court R, Waugh N (2012) Systematic review of SGLT2 receptor inhibitors in dual or triple therapy in type 2 diabetes. BMJ Open 2:e001007

49. Ferrannini E, Baldi S, Frascerra S, Astiarraga B, Heise T, Bizzotto R, Mari A, Pieber TR, Muscelli E (2016) Shift to fatty substrate utilization in response to sodium-glucose cotransporter 2 inhibition in subjects without diabetes and patients with type 2 diabetes. Diabetes. 65(5):1190-1195

50. Zinman B, Wanner C, Lachin JM, Fitchett D, Bluhmki E, Hantel S, Mattheus M, Devins T, Johansen OE, Woerle HJ, Broedl UC, Inzucchi SE, EMPA-REG OUTCOME Investigators (2015) EMPA-REG OUTCOME investigators. Empagliflozin, cardiovascular outcomes, and mortality in type 2 diabetes. N Engl J Med 373(22):2117-2128. https://doi.org/10.1056/NEJMoa1504720

51. Neal B, Perkovic V, Mahaffey KW, de Zeeuw D, Fulcher G, Erondu N, Shaw W, Law G, Desai M, Matthews DR, CANVAS Program Collaborative Group (2017) CANVAS program collaborative group. Canagliflozin and cardiovascular and renal events in type 2 diabetes. N Engl J Med 377(7):644-657. https://doi.org/10. 1056/NEJMoa1611925

52. Wiviott SD, Raz I, Bonaca MP, Mosenzon O, Kato ET, Cahn A, Silverman MG, Zelniker TA, Kuder JF, Murphy SA, Bhatt DL, Leiter LA, McGuire DK, Wilding JPH, Ruff CT, Gause-Nilsson IAM, Fredriksson M, Johansson PA, Langkilde AM, Sabatine MS (2019) DECLARE-TIMI 58 investigators. Dapagliflozin and cardiovascular outcomes in type 2 diabetes. N Engl J Med 380(4):347357. https://doi.org/10.1056/NEJMoa1812389

53. Zelniker TA, Wiviott SD, Raz I, Im K, Goodrich EL, Bonaca MP et al (2019) SGLT2 inhibitors for primary and secondary prevention of cardiovascular and renal outcomes in type 2 diabetes: a systematic review and meta-analysis of cardiovascular outcome trials. Lancet 393(10166):31-39. https://doi.org/10.1016/S01406736(18)32590-X Erratum in: Lancet. 2019 Jan 5;393(10166):30

54. Wanner C, Inzucchi SE, Lachin JM, Fitchett D, von Eynatten M, Mattheus M, Johansen OE, Woerle HJ, Broedl UC, Zinman B (2016) EMPA-REG OUTCOME investigators. Empagliflozin and progression of kidney disease in type 2 diabetes. N Engl J Med 375(4):323-334. https://doi.org/10.1056/NEJMoa1515920

55. Kadowaki T, Nangaku M, Hantel S, Okamura T, von Eynatten M, Wanner C et al (2019) Empagliflozin and kidney outcomes in Asian patients with type 2 diabetes and established cardiovascular disease: results from the EMPA-REG OUTCOME $<$ sup $>$ B $</$ sup $>$ trial. J Diabetes Investig 10(3):760-770. https://doi.org/10.1111/jdi.12971

56. Cherney DZI, Zinman B, Inzucchi SE, Koitka-Weber A, Mattheus M, von Eynatten M et al (2017) Effects of empagliflozin on the urinary albumin-to-creatinine ratio in patients with type 2 diabetes and established cardiovascular disease: an exploratory analysis from the EMPA-REG OUTCOME randomised, placebocontrolled trial. Lancet Diabetes Endocrinol 5(8):610-621. https:// doi.org/10.1016/S2213-8587(17)30182-1

57. Cooper ME, Inzucchi SE, Zinman B, Hantel S, von Eynatten M, Wanner C, Koitka-Weber A (2019) Glucose control and the effect of empagliflozin on kidney outcomes in type 2 diabetes: an analysis from the EMPA-REG OUTCOME trial. Am J Kidney Dis 74(5): 713-715. https://doi.org/10.1053/j.ajkd.2019.03.432

58. Sridhar VS, Rahman HU, Cherney DZI (2020) What have we learned about renal protection from the cardiovascular outcome trials and observational analyses with SGLT2 inhibitors? Diabetes Obes Metab 22(Suppl 1):55-68. https://doi.org/10.1111/dom. 13965

59. Perkovic V, de Zeeuw D, Mahaffey KW, Fulcher G, Erondu N, Shaw W, Barrett TD, Weidner-Wells M, Deng H, Matthews DR, Neal B (2018) Canagliflozin and renal outcomes in type 2 diabetes: results from the CANVAS program randomised clinical trials. Lancet Diabetes Endocrinol 6(9):691-704. https://doi.org/10. 1016/S2213-8587(18)30141-4

60. Mosenzon O, Wiviott SD, Cahn A, Rozenberg A, Yanuv I, Goodrich EL et al (2019) Effects of dapagliflozin on development and progression of kidney disease in patients with type 2 diabetes: an analysis from the DECLARE- TIMI 58 randomised trial. Lancet Diabetes Endocrinol 7(8):606-617. https://doi.org/10.1016/S22138587(19)30180-9 Erratum in: Lancet Diabetes Endocrinol. 2019 Aug;7(8):e20

61. Zelniker TA, Wiviott SD, Raz I, Im K, Goodrich EL, Furtado RHM, Bonaca MP, Mosenzon O, Kato ET, Cahn A, Bhatt DL, Leiter LA, McGuire DK, Wilding JPH, Sabatine MS (2019) Comparison of the effects of glucagon-like peptide receptor agonists and sodium-glucose cotransporter 2 inhibitors for prevention of major adverse cardiovascular and renal outcomes in type 2 diabetes mellitus. Circulation. 139(17):2022-2031

62. Jardine MJ, Mahaffey KW, Perkovic V (2019) Canagliflozin and renal outcomes in diabetic nephropathy. Reply N Engl J Med 381(11):1089-1090. https://doi.org/10.1056/NEJMc1909687

63. Cherney DZI, Heerspink HJL, Frederich R, Maldonado M, Liu J, Pong A, Xu ZJ, Patel S, Hickman A, Mancuso JP, Gantz I, Terra SG (2020) Effects of ertugliflozin on renal function over 104 weeks of treatment: a post hoc analysis of two randomised controlled trials. Diabetologia. 63(6):1128-1140

64. Cherney DZI, Dekkers CCJ, Barbour SJ, Cattran D, Abdul Gafor AH, Greasley PJ et al (2020) Effects of the SGLT2 inhibitor dapagliflozin on proteinuria in non-diabetic patients with chronic kidney disease (DIAMOND): a randomised, double-blind, crossover trial. Lancet Diabetes Endocrinol 8(7):582-593. https://doi. org/10.1016/S2213-8587(20)30162-5 Erratum in: Lancet Diabetes Endocrinol. 2020 Jun 25

Publisher's note Springer Nature remains neutral with regard to jurisdictional claims in published maps and institutional affiliations. 